\title{
Erratum to: Effect of Bio-stimulants on Yield and Quality of Head Lettuce Grown Under Two Sources of Nitrogen
}

Sami M. Shehata ${ }^{1} \cdot$ U. Schmidhalter ${ }^{2} \cdot$ Magdaléna Valšíková $^{3} \cdot$ H. Junge ${ }^{4}$

Published online: 3 March 2016

(C) Springer-Verlag Berlin Heidelberg 2016

\section{Gesunde Pflanzen (2016)}

The name of the second author was rendered incorrectly in the original publication but has since been corrected: instead of U. Schmidthalter it should read U. Schmidhalter.

The online version of the original article can be found under doi:10.1007/s10343-016-0357-5

Sami M. Shehata

sami.shehata@gmail.com

1 Vegetable Research Department, National Research Center, Cairo, Ägypten

2 Lehrstuhl für Pflanzenernährung, Technische Universität München, Munich, Deutschland

3 Slovak University of Agriculture in Nitra, Nitra, Slovak Republic, Slovakia

4 ABiTEP GmbH, Glienicker Weg 185, 12489 Berlin, Deutschland 